\title{
Effect of Essential Oil of Laurel (Laurus nobilis L.) on Performance, Blood and Fecal Parameters of Holstein Calves during Suckling Period
}

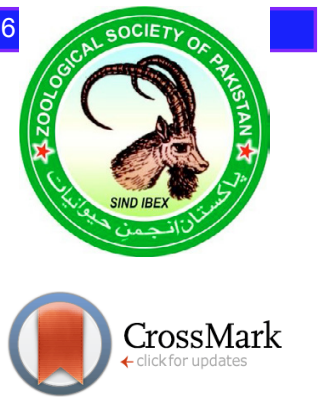

\author{
Shireen Ihsan Izzaddeen ${ }^{1}$ and Ali Kaygısiz ${ }^{2, *}$ \\ ${ }^{1}$ Department of Animal Science, College of Agriculture, University of Salahaddin, \\ Erbil, Iraq \\ ${ }^{2}$ Department of Animal Science, Faculty of Agriculture, University of Kahramanmaras \\ Sütçü Imam, Kahramanmaraş, Türkiye
}

\begin{tabular}{l} 
Article Information \\
Received 26 August 2016 \\
Revised 13 August 2017 \\
Accepted 30 November 2017 \\
Available online 23 April 2018 \\
Authors' Contribution \\
\hline AK and SII designed the study \\
and collected the data. SII and AK \\
executed the experimental work and \\
wrote the article. \\
Key words \\
Holstein Friesian calf, Essential \\
laurel (Laurus nobilis L.) oil, Growth \\
performance, Diarrhea score, Blood \\
parameters.
\end{tabular}

\begin{abstract}
A B S T RA C T
The objective of this study was to analyze the effect of Laurus nobilis L. essential oil (600 mg/day) on performance and blood parameters of Holstein calves. The study was started with total of 24 calves, randomly categorized into two groups of 12 (6 males and 6 females) however, it was completed with 23 calves because of dying a female at the $8^{\text {th }}$ week of the trial. Addition of Laurel essential oil into whole milk did not cause any significant change in weekly live weight gain $(\mathrm{kg})$, total weaning live weight gain $(\mathrm{kg})$, weekly chest girth measurements $(\mathrm{cm})$, weaning chest girth $(\mathrm{cm})$, dry matter, roughage and concentrate feed consumption (gr), total milk consumption $(\mathrm{kg})$, feed conversion ratio $(\mathrm{kg})$, total cost and unit cost $(\mathrm{P}>0.05)$. However, essential oil contained calf's milk decreased fecal evaluation score and number of days with diarrhea $(\mathrm{P}<0.05)$. The calf's serum total cholesterol, glucose, AST, GGT, creatinine, phosphor, calcium, insulin, total T3, total T4, albumin, GH and globulin concentrations did not differ between the groups $(\mathrm{P}>0.05)$. Essential laurel oil containing whole milk, on the other hand, lowered serum triglyceride concentration $(\mathrm{P}<0.05)$. Altogether these results suggested that the consumption of laurel essential oil $(600 \mathrm{mg} /$ day) containing whole milk by calves might have positive influences on their health parameters compared to the control group.
\end{abstract}

\section{INTRODUCTION}

C Talf diarrhea causes considerable economic losses in calf rearing around the world due to the growth deficiency, deaths and treatment expenses (Radostits et al., 2008). In order to provide protection against the disease and improve the performance of animals, antibiotics such as ionospheres, are commonly used as a feed additive in animal nutrition. It has been previously shown that use of antibiotics as feed additives not only improved the performance as a result of their desirable effects on feed consumption, feed conversion and feces density but also lowered the death rate by advancing the health of animals (Berge et al., 2005; Donovan et al., 2002; Morrill et al., 1977).

Constant use of antibiotics, however, may reduce the animal's resistance to microorganisms and consequently diminish ability to combat the diseases caused by microbial

\footnotetext{
* Corresponding author: alikaygisiz@ksu.edu.tr 0030-9923/2018/0003-1087 \$ 9.00/0

Copyright 2018 Zoological Society of Pakistan
}

agents. Besides, antibiotic residues in diary products reach a critical level where it threatens the human and animal health due to their carcinogenic and mutagenic properties. It has been also clearly demonstrated that the bacteria, which gained resistance against certain antimicrobial agents over time, could constitute severe problems to combat the disease (Altundağ and Aslım, 2005; Koçyiğit et al. 2016). Due to these apparent concerns, the use of antibiotics in animal feed as growth promoting additives was prohibited in European Union in 2005 followed by Turkey in 2006 (Anonymous, 2002, 2005, 2006).

In pursuit of the prohibition of antibiotics as growth stimulants, the researchers focused on studies in enzymes, organic acids, probiotics, prebiotics and natural and reliable products containing phytobiotics (Karayağız and Bülbül, 2014). Especially phytobiotics captured special attention for their antimicrobial, antioxidant, immune stimulant effects, as well as an improver effect on feed consumption, feed conversion and performance (Kutlu and Erdoğan, 2010). Inevitably, use of medicinal plants as an alternative to drugs are recommended to prevent developing possible resistance to known antimicrobial growth stimulants and 
bacteria (Abascal and Yarnell, 2002).

Several studies revealed that some aromatic herbs bear antibacterial, antifungal and antiviral effects along with promoting digestion activities (Helander et al., 1998). In addition, Wenk (2000) reported that the herbal extracts, which generally enhance the flavor of the feed, increased digestive secretions and provided an increase in yield by stimulating the protein synthesis whereas McIntosh et al. (2000) mentioned that the essential oils reduced the ammonium production and decreased the number of harmful bacteria.

The laurel essential oil naturally contains 1.8 Cineol by $35-50 \%$ (Ertekin et al., 2009). Cineol is the active substance of laurel and retain a broad antimicrobial efficiency against both gram positive and gram negative bacteria (Çabuk et al., 2003; Smith-Palmer et al., 2002; Evren and Tekgüler, 2011).

Moreover, in a study conducted by Spanghero et al. (2007), it has been exhibited that essential oil as feed additive in Holstein calves at suckling period increased the daily body weight gain and enhanced the feed conversion ratio while another group lead by Youssef et al. (2008) reported that it boosted performance and immune system enhancement in buffalo calves at the same period. Essential oil has also been shown to improve the body weight gain, feed intake and feed conversion and led to a decrease in fecal score, number of fecal coliform, number of days with diarrhea and unit of body weight cost (Ghosh et al., 2010a, b, 2011). Additionally, Ozalpaydin (2014) demonstrated how positively it affected the total milk consumption, daily roughage and feed intake, feed conversion ratio, weaning age, starting roughage and concentrate feed and fecal score whereas its growth and immune system promoting effects were revealed by Garcia et al. (2015).

Although there is an accumulating amount of evidence which indicates the advantageous properties of essential oil supplementation on the well-being of different species of livestock, there has been no study to investigate the effect of Laurus nobilis L. essential oil on body weight, chest girth size, feed conversion rate and blood parameters of Holstein calves. Therefore, in this study, we aimed to examine how feeding Holstein calves with $600 \mathrm{mg}$ /day of Laurus nobilis L. essential oil containing milk till weaning would influence above mentioned parameters in the calves grown in farming conditions.

\section{MATERIALS AND METHODS}

\section{Material}

Twenty-four newly born Holstein Friesian calves from a private dairy farm located in Kahramanmaraş were subjected to the study. The calves were weighed within
$24 \mathrm{~h}$ of birth and placed in sheds individually. They were assigned to two treatment groups of twelve randomly based on their sexes ( 6 males, 6 females). However, a female calf in the control group died on the $8^{\text {th }}$ week of the trial, therefore, the trial was completed with 23 calves.

\section{Methods}

The calves were taken away from their mothers' right after delivery and placed in individual sections. In the first four days of birth, calves were fed with colostrum (10\% of their birth weight) via milk bottles. From the fifth day on, they began to be fed with 5.5-6 liters of whole milk, three times a day; in the morning, in the evening and at night. The temperature of the feeding milk was at $39-40^{\circ} \mathrm{C}$.

The calves were presented with fresh drinking water as needed from the 3rd day and nourished with pellet starter feed and straw from the $7^{\text {th }}$ day of the birth. These conditions were maintained until the end of the study. Pellet and straw were weighted in separate plastic containers and the intakes were recorded daily.

The essential laurel oil (Laurus nobilis L.) used in the research were purchased from local market of Hatay, Türkiye and stored at $4{ }^{\circ} \mathrm{C}$. The essential laurel oil (Laurus nobilis L.) contains 41.52\% 1.8-Cineol in material (Karaoğul et al., 2012). It was added to the whole milk by which the calves would be fed in such amount that each animal would receive $600 \mathrm{mg} /$ day. The feeding of the calves with oil supplemented milk was initiated on the $5^{\text {th }}$ day after their birth. The body weights of calves were measured weekly through a scale with $0.1-\mathrm{kg}$ sensitivity. A portable tank was used for heating, mixing and homogenization of the milk. A standard tape was used to measure the chest girth of each calf.

The growth parameters such as daily weight gain, daily feed consumption, feed conservation ratio, weaning weight, and chest girth size were recorded daily. Fecal scores based on a four-point scale were also documented daily as described by Larson et al. (1977).

In order to calculate the body weight unit gain cost by the time of weaning, the price of $1 \mathrm{~kg}$ of concentrate feed, $1 \mathrm{~kg}$ of roughage and $1 \mathrm{~L}$ of milk were considered as 1 TL (Turkish Lira), 0.20 TL, and 1.15 TL, respectively. The costs of labor and calf's diarhea treatment were determined as 18.52 and 3.5 TL, in respect to their order. The body weight gain cost was calculated by dividing the total amount of expenditure until the time of weaning by total body weight gain.

\section{Statistical analysis}

Recorded parameters of the study including intakes of roughage, concentrate feed and milk, blood parameters, body weight gain costs, fecal evaluation scores and number 
of days with diarrhea were subjected to general linear model (GLM) procedure. The periodical weights were computed with repeated measurements of variance analysis. Means were separated by Duncan Multiple Comparison Test, and mean comparisons of repeated measurements were tested by Bonferroni Multiple Comparison Test (SAS, 2000).

The mathematical model used was as follows:

For periodical weight, intakes of roughage, concentrate feed and milk, blood parameters, body weight costs, fecal evaluation scores and number of days with diarrhea:

$$
Y_{i j k}=\mu+a_{i}+b_{j}+e_{i j k}
$$

For periodical weights:

$$
Y_{i j k}=\mu+a_{i}+b_{j}+c_{k}+e_{i j k}
$$

Where, $\mathrm{Y}$ is performance traits, $\mu$ is population mean, $\mathrm{a}_{\mathrm{i}}$ is treatment effect, $b_{j}$ is effect of sex, $c_{k}$ is period effect and $\mathrm{e}_{\mathrm{ijk}}$ is normal, independent and occasional error.

\section{RESULTS AND DISCUSSION}

\section{Growth performance of calves}

The mean birth weights and weekly body weights at the beginning of the trial are presented in Table I. The birth weights between the sexes and treatment groups were found not to differ significantly $(\mathrm{P}>0.05)$. Thus, it was possible to state that the treatment groups were distributed homogeneously in terms of birth weights.

However, the sex effect on body weights was determined as statistically significant for at the 2nd, 3rd, 4th, 7th and 8th weeks after the birth $(\mathrm{P}<0.05)$ although it was not so for other weeks studied $(\mathrm{P}>0.05)$. Nevertheless, male calves were numerically heavier than female calves from birth to the weaning without a statistically significant difference between them.

When the body weights of the animals in the control and the treatment group were compared, it was revealed the values were considerably higher for the treatment groups at the 2 nd and $3 r d$ weeks $(\mathrm{P}<0.05)$ whereas the difference between them was statistically insignificant for the other weeks ( $\mathrm{P}>0.05)$. Besides, the calves fed with laurel oil (Laurus nobilis L.) supplemented diet exhibited better performance in comparison with the control group in terms of weekly body weight. Compared to the control group, weaning body weights of laurel oil presented calves were $6.5,8.7,7.7,5.6,1.3,3.9,2.3,3.9$ and $1.7 \%$ greater for the 1st, 2nd, 3rd, 4th, 5th, 6th, 7th, 8th weeks, respectively.

Previous studies done in different laboratories have reported that adding carvacrol, cinnamic aldehyde, thyme oil or thymol to lamb rations increased the body weight gain, albeit non significantly (Chavez et al., 2008; Simitzis et al., 2008; Ünal, 2011). Similarly, Tunç (2012) reported that adding humate and propionic acid to calf rations had a positive effect on body weight gain whilst Akkan (2013) showed that saccharomyces and/or manan oligosaccharide supplements in calf rations did not make any effects. On the other hand, including essential oils (Spanghero et al., 2007), garlic oil (Ahmed et al., 2009; Ghosh et al., 2010a, b, 2011), probiotcs (Büyükkılıç-Beyzi, 2012), thymol and carvacrol (Van der Vliet and Cardozo, 2013), thyme oil (Özalpaydın, 2014) in calf and buffalo calf rations improved the body weight gains.

Table I.- Mean values, variance analysis, significance and multiple comparison test results of calf's body weights

\begin{tabular}{|c|c|c|c|c|c|}
\hline \multirow[t]{2}{*}{ Traits } & \multirow{2}{*}{$\begin{array}{c}\text { General } \\
(n=23)\end{array}$} & \multicolumn{2}{|c|}{ Sex } & \multicolumn{2}{|c|}{ Treatment } \\
\hline & & Male $(n=12)$ & Female $(n=11)$ & Laurel $(n=12)$ & Control $(n=11)$ \\
\hline Birth Weight & $44.00 \pm 1.12$ & $45.73 \pm 1.59$ & $41.96 \pm 1.67$ & $44.41 \pm 1.59$ & $43.28 \pm 1.67$ \\
\hline Week I & $46.98 \pm 1.03$ & $48.88 \pm 1.37$ & $44.91 \pm 1.43$ & $48.38 \pm 1.37$ & $45.41 \pm 1.43$ \\
\hline Week II & $50.35 \pm 1.04$ & $52.03 \pm 1.33^{\mathrm{a}}$ & $48.53 \pm 1.40^{b}$ & $52.38 \pm 1.33^{\mathrm{a}}$ & $48.18 \pm 1.40^{b}$ \\
\hline Week III & $52.90 \pm 0.94$ & $54.71 \pm 1.16^{\mathrm{a}}$ & $50.87 \pm 1.21^{\mathrm{b}}$ & $54.76 \pm 1.16^{\mathrm{a}}$ & $50.82 \pm 1.21^{b}$ \\
\hline Week IV & $56.50 \pm 0.89$ & $58.26 \pm 1.11^{\mathrm{a}}$ & $54.27 \pm 1.16^{\mathrm{b}}$ & $57.81 \pm 1.11$ & $54.72 \pm 1.16$ \\
\hline Week V & $60.65 \pm 0.83$ & $62.15 \pm 1.16$ & $58.96 \pm 1.21$ & $60.96 \pm 1.16$ & $60.14 \pm 1.21$ \\
\hline Week VI & $65.52 \pm 0.88$ & $66.93 \pm 1.19$ & $63.77 \pm 1.24$ & $66.61 \pm 1.19$ & $64.09 \pm 1.24$ \\
\hline Week VII & $70.66 \pm 0.85$ & $72.31 \pm 1.14^{\mathrm{a}}$ & $68.79 \pm 1.20^{\mathrm{b}}$ & $71.38 \pm 1.14$ & $69.73 \pm 1.20$ \\
\hline Week VIII & $74.89 \pm 0.96$ & $76.60 \pm 1.21^{\mathrm{a}}$ & $72.90 \pm 1.26^{\mathrm{b}}$ & $76.21 \pm 1.21$ & $73.28 \pm 1.26$ \\
\hline Weaning Weight & $77.49 \pm 1.19$ & $79.53 \pm 1.59$ & $75.21 \pm 1.66$ & $78.03 \pm 1.59$ & $76.71 \pm 1.66$ \\
\hline Body Weight Gain & $33.53 \pm 1.21$ & $34.89 \pm 1.55$ & $32.02 \pm 1.63$ & $33.89 \pm 1.51$ & $33.01 \pm 1.58$ \\
\hline
\end{tabular}
(kg).

a,b, The differences between the mean values indicated with different letters on the same column are significant $(\mathrm{P}<0.05)$. 
Table II.- Mean values, variance analysis, significance and multiple comparison test results of calf's chest girth sizes (cm).

\begin{tabular}{|c|c|c|c|c|c|}
\hline \multirow[t]{2}{*}{ Traits } & \multirow{2}{*}{$\begin{array}{c}\text { General } \\
(n=23)\end{array}$} & \multicolumn{2}{|c|}{ Sex } & \multicolumn{2}{|c|}{ Treatment } \\
\hline & & Male $(n=12)$ & Female $(n=11)$ & Laurel $(n=12)$ & Control $(n=11)$ \\
\hline Birth & $81.64 \pm 0.74$ & $82.20 \pm 1.05$ & $80.59 \pm 1.10$ & $81.87 \pm 1.05$ & $80.92 \pm 1.10$ \\
\hline Week I & $84.37 \pm 0.61$ & $85.16 \pm 0.86$ & $83.55 \pm 0.90$ & $85.25 \pm 0.86$ & $83.47 \pm 0.90$ \\
\hline Week II & $86.95 \pm 0.54$ & $87.33 \pm 0.75$ & $86.35 \pm 0.78$ & $87.91 \pm 0.75$ & $85.77 \pm 0.78$ \\
\hline Week III & $88.33 \pm 0.56$ & $89.08 \pm 0.70$ & $87.25 \pm 0.73$ & $89.41 \pm 0.70^{a}$ & $86.91 \pm 0.73^{b}$ \\
\hline Week IV & $90.12 \pm 0.47$ & $90.50 \pm 0.54$ & $89.50 \pm 0.56$ & $91.50 \pm 0.54^{\mathrm{c}}$ & $88.00 \pm 0.56^{\mathrm{d}}$ \\
\hline Week V & $91.75 \pm 0.43$ & $92.25 \pm 0.59$ & $91.11 \pm 0.62$ & $92.41 \pm 0.59$ & $90.94 \pm 0.62$ \\
\hline Week VI & $93.95 \pm 0.42$ & $94.25 \pm 0.59$ & $93.66 \pm 0.62$ & $94.66 \pm 0.59$ & $93.24 \pm 0.62$ \\
\hline Week VII & $96.08 \pm 0.49$ & $96.50 \pm 0.72$ & $95.67 \pm 0.75$ & $96.66 \pm 0.72$ & $95.50 \pm 0.75$ \\
\hline Week VIII & $98.08 \pm 0.51$ & $98.58 \pm 0.64$ & $97.44 \pm 0.67$ & $99.08 \pm 0.64^{\mathrm{a}}$ & $96.94 \pm 0.67^{b}$ \\
\hline Weaning & $100.04 \pm 0.58$ & $100.66 \pm 0.74$ & $99.26 \pm 0.77$ & $101.08 \pm 0.74^{\mathrm{a}}$ & $98.84 \pm 0.77^{b}$ \\
\hline
\end{tabular}

a,b , The differences between the mean values indicated with different letters on the same column are significant $(\mathrm{P}<0.05)$; ${ }^{c, d}$, The differences between the mean values indicated with different letters on the same column are significant $(\mathrm{P}<0.01)$.

The mean total body weight gain for, laurel fed group, control group and both groups combined were, $33.89 \mathrm{~kg}$, $33.01 \mathrm{~kg}$, and $33.53 \pm 1.21 \mathrm{~kg}$, respectively. Until the weaning, the effects of sex and treatment factors on the total body weight gain were not significant $(\mathrm{P}>0.05)$. The calves in both sex groups and the calves in both trial groups gained weight up to $76 \%$ of their birth weight by the time of weaning. This finding was in accordance with a relatively recent study by Vakili et al. (2013) which also demonstrated that essential thyme or cinnamon oil additions to rations did not have any effect on daily body weight gain of the animals studied.

During the experimental period, 6 liters of milk and the laurel oil ( $600 \mathrm{mg} /$ day $)$ were given to the calves every day. Considering the fact that the main active ingredient of laurel oil is 1.8 -Cineol and it consists of nearly $41.52 \%$ of the mass, it was calculated that, during this period from the $1^{\text {st }}$ week of study to the time of weaning, 8.17, 7.62, 7.25, $6.79,6.33,5.86,5.43,5.12$ and $4.95 \mathrm{mg}$ of 1.8 -Cineol per $\mathrm{kg}$ body weight were given to the calves, respectively.

Low level of the active ingredient given per $\mathrm{kg}$ of body weight and small sample size may have caused an insignificant effect.

\section{Chest girth measurements}

The chest girth sizes of calves in both groups were measured weekly (Table II). The chest girth size was used as an indicator of growth-development and as an important parameter when the periodical body weight measurements were undetectable. In our study, there was no difference of chest girth at birth between sex and treatment groups $(\mathrm{P}>0.05)$. Thus, it is possible to state that the trial groups were assigned homogeneously in terms of chest girth at birth.

Within the period until weaning, the effect of sex factor on chest girth size was non-significant $(\mathrm{P}>0.05)$. However, from birth to weaning, the chest girth sizes of males were greater than those of females.

The treatment had a significant impact on the chest girth size of the calves on the $3 \mathrm{rd}$ and the 8 th weeks, and at weaning time $(\mathrm{P}<0.05)$. While this impact showed its peak at week $4(\mathrm{P}<0.01)$, it was found to be insignificant for the remaining weeks $(\mathrm{P}>0.05)$.

The calves in laurel group sustained greater chest girth size compared to the control. In terms of weekly chest girth sizes, the calves in laurel group performed better than the control group. In terms of $1 \mathrm{st}, 2 \mathrm{nd}, 3 \mathrm{rd}, 4 \mathrm{th}, 5 \mathrm{th}, 6 \mathrm{th}$, 7 th, $8^{\text {th }}$ week and at the time of weaning, the calves fed with laurel oil had larger chest girth size as compared to the control group by $2.1,2.4,2.8,3.3,1.6,1.5,1.2,2.2$ and $2.2 \%$ seriatim.

\section{Milk and feed and dry matter intake}

Intakes of milk, roughage and concentrate feed, dry matter, and feed conservation ratio are presented in Table III. The total milk consumption per calf was $305.41 \mathrm{~kg}$ until weaning, and the effects of sex and treatment on it were insignificant $(\mathrm{P}>0.05)$. However, over the course of study, male calves consumed in avarage $27.53 \mathrm{~kg}$ more milk than female calves, and calves in control group consumed 18.8 $\mathrm{kg}$ more milk in comparison to those of treatment group.

Roughage and concentrate feed intakes were 1.68 and $22.71 \mathrm{~kg} /$ calf by the weaning. Following the colostrum feeding, the treatment program was applied with concentrate feeding. There was no sex effect on concentrate and roughage feed intakes $(\mathrm{P}>0.05)$. 
Table III.- Calf's milk, roughage, concentrate intakes, calf's dry matter intake and feed conversion ratio (kg).

\begin{tabular}{|c|c|c|c|c|c|}
\hline \multirow[t]{2}{*}{ Traits } & \multirow{2}{*}{$\begin{array}{c}\text { General } \\
(n=23)\end{array}$} & \multicolumn{2}{|c|}{ Sex } & \multicolumn{2}{|c|}{ Treatment } \\
\hline & & Male $(n=12)$ & Female $(n=11)$ & Laurel $(n=12)$ & Control $(\mathrm{n}=11)$ \\
\hline Roughage intake & $1.68 \pm 0.11$ & $1.61 \pm 0.17$ & $1.76 \pm 0.17$ & $1.66 \pm 0.16$ & $1.71 \pm 0.17$ \\
\hline Concentrate feed intake & $22.71 \pm 1.38$ & $23.03 \pm 2.11$ & $22.43 \pm 2.22$ & $22.05 \pm 2.05$ & $23.40 \pm 2.15$ \\
\hline Milk consumption & $305.41 \pm 7.40$ & $318.98 \pm 8.50$ & $291.45 \pm 8.93$ & $295.82 \pm 8.26$ & $314.62 \pm 8.66$ \\
\hline Dry Matter & $60.93 \pm 1.92$ & $62.91 \pm 2.74$ & $58.93 \pm 2.88$ & $59.09 \pm 2.66$ & $62.75 \pm 2.79$ \\
\hline Feed Conversion ratio & $1.84 \pm 0.06$ & $1.84 \pm 0.08$ & $1.85 \pm 0.08$ & $1.74 \pm 0.07$ & $1.94 \pm 0.08$ \\
\hline
\end{tabular}

Table IV.- Calf's cost of body weight gain (TL).

\begin{tabular}{|c|c|c|c|c|c|}
\hline \multirow[t]{2}{*}{ Traits } & \multirow{2}{*}{$\begin{array}{c}\text { General } \\
(n=23)\end{array}$} & \multicolumn{2}{|c|}{ Sex } & \multicolumn{2}{|c|}{ Treatment } \\
\hline & & Male $(n=12)$ & Female $(n=11)$ & Laurel $(\mathrm{n}=12)$ & Control $(\mathrm{n}=11)$ \\
\hline Total cost & $425.15 \pm 10.26$ & $437.64 \pm 12.86$ & $413.38 \pm 13.46$ & $404.94 \pm 12.86^{\mathrm{a}}$ & $446.07 \pm 13.46^{b}$ \\
\hline Unit cost & $12.92 \pm 0.42$ & $13.26 \pm 0.54$ & $12.62 \pm 0.57$ & $12.15 \pm 0.54$ & $13.72 \pm 0.57$ \\
\hline
\end{tabular}

a,b, The differences between the mean values indicated with different letters on the same column are significant $(\mathrm{P}<0.05)$.

The total concentrate and roughage feed intakes over course of the study was $22.05 \pm 2.05$ and $1.66 \pm 0.16 \mathrm{~kg}$ in laurel group and $23.40 \pm 2.15$ and $1.71 \pm 0.17 \mathrm{~kg}$ in control group, respectively. There was no statistical differences of feed intake between the groups $(\mathrm{P}>0.05)$. Addition of laurel oil to milk during suckling period did not have any negative effect on roughage and concentrate feed intakes as expected. The roughage and concentrate feed intakes were higher in calves receiving laurel oil by 3 and $6 \%$, respectively compared to the control group although this difference was not statistically significant $(\mathrm{P}>0.05)$.

Studies by Alçiçek et al. (2003), Dziba et al. (2006), Chaves et al. (2008), Benchaar et al. (2006), Cardozo et al. (2006), Ahmed et al. (2009), Soltan (2009), Yang et al. (2010), Tunç (2012), and Vakili et al. (2013) indicated that addition of essential oil acid and/or herbal extracts to rations did not have an effect on feed intakes, which corroborate our results.

The 1.8-Cineol in laurel oil may cause an inhibition of rumen microorganisms and decreasing bacteria in rumen liquid resulting in limitation of the fermentation and decrease in the feed conversion level. Total dry matter intake in male and female calves was 62.91 and $58.93 \mathrm{~kg}$, respectively. Although it was not significant, male calves consumed $6.75 \%$ more dry matter than female calves. On the other hand, dry matter intake of laurel fed and control groups were 59.09 and $62.75 \mathrm{~kg}$, respectively, which corresponded to a $6 \%$ greater dry matter in treated calves than those of control groups.

\section{Feed conversion}

During the experiment period, calves consumed an average of $1.84 \mathrm{~kg}$ dry matter per $\mathrm{kg}$ of body weight gain. No significant effect of sex and treatment on feed conversion ratio was found $(\mathrm{P}>0.05)$. The feed conversion ratio was considerably similar also in male and female calves (1.84 and 1.85). Whereas, calves in laurel group needed $0.20 \mathrm{~kg}(10 \%)$ less nourishment per $\mathrm{kg}$ of body weight gain compared to those of control group although it was not a statistically significant $(\mathrm{P}>0.05)$

\section{Costs of body weight gain}

The cost of body weight gain of the calves is presented in Table IV. No significant effect of sex and treatment on cost of body weight gain was found in the trial $(\mathrm{P}>0.05)$.

The unit body weight costs in laurel supplemented and control groups were calculated as 12.15 and 13.72 TL (Turkish Lira), respectively. The unit body weight gain cost of the calves in laurel group was numerically $11 \%$ cheaper than the control group. On the other hand, the body weight gain cost in female and male calves were estimated as 12.62 and $13.26 \mathrm{TL}$, respectively, which corresponded to a $5 \%$ less expense for females. Contrary to our results, previous researchers reported that adding carvacrol, cinnamic aldehyde, thyme oil or thymol to lamb rations increased the body weight, though their effects were not statistically significant (Ghosh et al, 2010a, b, 2011; Chavez et al., 2008; Simitzis et al., 2008; Ünal, 2011).

\section{Fecal scoring}

During the study, the fecal evaluation was performed weekly, and the relevant scores are shown in Table V. The treatment effect on weekly fecal evaluation score was 
found significantly different for only the 1st (diarrhea right after the birth was common) 4 th and the 5th weeks $(\mathrm{P}<0.01)$. The diarrhea score in laurel group was lower than the control. The sex effect on weekly diarrhea score was not significant $(\mathrm{P}>0.05)$ with the exception of the $3 \mathrm{rd}$ week.

Earlier researchers (Ghosh et al., 2010a, b, 2011; Van der Vliet and Cardozo, 2013) reported that adding essential oil acid and/or herbal extract to rations decreased diarrhea score, which was in agreeement with the present results.

\section{Number of days with diarrhea}

While the number of the days with and without diarrhea in laurel group was 33.00 and 23.00, respectively, the respective values in control group were 34.73 and 20.82 (Table VI). Adding laurel oil to calf milk decreased the number of days with diarrhea significantly $(\mathrm{P}<0.05)$. Results of earlier studies also confirmed our results (Ghosh et al., 2010a, b, 2011; Büyükkılıç-Beyzi, 2012; Van der Vliet and Cardozo, 2013; Akkan, 2013; Özalpaydın, 2014). Blood parameters

Table V.- Number of days with diarrhea.
Blood samples of twenty three calves were taken individually, and parameters including Albumin, aspartate aminotranspherase (AST), phosphorus, gama-glutamyltranspherase (GGT), glucose, calcium (Ca), cholesterol, triglyceride, tetraiodotironin (T4), triiodotirnonin (T3), globulin, insulin, growth hormone (GH) and creatinine levels were analyzed (Table VII).

Sex did not affect any blood parameters of calves with the exception of triiodotironin (T3) $(\mathrm{P}<0.05)$. Additionally, the treatment was found to be not influencing any blood parameters other than triglyceride levels $(\mathrm{P}<0.05)$. Similar results about blood parameters were also revealed by Sirakaya (2008) and Vakili et al. (2013).

The main active ingredient of laurel oil is 1.8-Cineol by $41.52 \%$. Triglyceride concentration of calves in laurel group was discovered to be lower than the control group $(\mathrm{P}<0.05)$. Ünlü and Erkek (2013) also reported comparable results, inferring that adding thyme and garlic essential oils to whole milk would lower serum cholesterol levels $(\mathrm{P} \leq 0.05)$.

\begin{tabular}{|c|c|c|c|c|c|}
\hline \multirow[t]{2}{*}{ Traits } & \multirow{2}{*}{$\begin{array}{c}\text { General } \\
(n=23)\end{array}$} & \multicolumn{2}{|c|}{ Sex } & \multicolumn{2}{|c|}{ Treatment } \\
\hline & & Male $(n=12)$ & Female $(n=11)$ & Laurel $(n=12)$ & Control $(n=11)$ \\
\hline Number of normal days & $27.17 \pm 2.01$ & $26.50 \pm 2.22$ & $27.35 \pm 2.33$ & $33.00 \pm 2.22^{c}$ & $20.85 \pm 2.33^{d}$ \\
\hline Number of soft days & $20.52 \pm 1.57$ & $20.33 \pm 1.64$ & $21.19 \pm 1.72$ & $15.66 \pm 1.64^{\mathrm{c}}$ & $25.85 \pm 1.72^{\mathrm{d}}$ \\
\hline Number of loose days & $6.13 \pm 0.66$ & $6.58 \pm 0.87$ & $5.74 \pm 0.91$ & $5.00 \pm 0.87$ & $7.32 \pm 0.91$ \\
\hline Number of liquid days & $1.95 \pm 0.28$ & $2.16 \pm 0.38$ & $1.69 \pm 0.40$ & $2.33 \pm 0.38$ & $1.52 \pm 0.40$ \\
\hline Number of days with diarrhea & $28.60 \pm 1.95$ & $29.08 \pm 2.18$ & $28.62 \pm 2.28$ & $23.00 \pm 2.18^{c}$ & $34.70 \pm 2.28^{\mathrm{d}}$ \\
\hline
\end{tabular}

c,d The differences between the mean values indicated with different letters on the same column are significant $(\mathrm{P}<0.01)$.

Table VI.- Calf's fecal evaluation scores by weeks.

\begin{tabular}{|c|c|c|c|c|c|}
\hline \multirow[t]{2}{*}{ Traits } & \multirow{2}{*}{$\begin{array}{c}\text { General } \\
(n=23)\end{array}$} & \multicolumn{2}{|c|}{ Sex } & \multicolumn{2}{|c|}{ Treatment } \\
\hline & & Male (n=12) & Female $(n=11)$ & Laurel $(n=12)$ & Control $(n=11)$ \\
\hline Week I & $12.54 \pm 1.00$ & $11.16 \pm 0.97$ & $13.46 \pm 1.02$ & $9.25 \pm 0.97^{\mathrm{c}}$ & $15.37 \pm 1.02^{d}$ \\
\hline Week II & $14.54 \pm 0.89$ & $14.22 \pm 1.40$ & $14.91 \pm 1.36$ & $15.08 \pm 1.34$ & $14.05 \pm 1.40$ \\
\hline Week III & $13.79 \pm 0.89$ & $16.16 \pm 1.12^{a}$ & $11.57 \pm 1.17^{b}$ & $13.58 \pm 1.12$ & $14.15 \pm 1.17$ \\
\hline Week IV & $9.87 \pm 0.58$ & $10.25 \pm 0.72$ & $9.09 \pm 0.76$ & $8.58 \pm 0.72^{a}$ & $10.76 \pm 0.76^{b}$ \\
\hline Week V & $10.91 \pm 0.64$ & $11.00 \pm 0.79$ & $10.80 \pm 0.82$ & $9.08 \pm 0.79^{\mathrm{a}}$ & $12.71 \pm 0.82^{b}$ \\
\hline Week VI & $11.45 \pm 0.60$ & $11.16 \pm 0.89$ & $11.98 \pm 0.93$ & $11.75 \pm 0.89$ & $11.40 \pm 0.93$ \\
\hline Week VII & $10.70 \pm 0.69$ & $10.33 \pm 1.03$ & $10.90 \pm 1.07$ & $10.66 \pm 1.03$ & $10.57 \pm 1.07$ \\
\hline Week VIII & $11.34 \pm 0.72$ & $11.08 \pm 1.00$ & $11.73 \pm 1.04$ & $10.33 \pm 1.00$ & $12.48 \pm 1.04$ \\
\hline
\end{tabular}

a,b , The differences between the mean values indicated with different letters on the same column are significant $(\mathrm{P}<0.05)$; ${ }^{\mathrm{c}, \mathrm{d}}$, The differences between the mean values indicated with different letters on the same column are significant $(\mathrm{P}<0.01)$. 
Table VII.- Mean values, variance analysis, significance and multiple comparison test results of calf's blood values.

\begin{tabular}{|c|c|c|c|c|c|}
\hline \multirow[t]{2}{*}{ Traits } & \multirow{2}{*}{$\begin{array}{c}\text { General } \\
(n=23)\end{array}$} & \multicolumn{2}{|c|}{ Sex } & \multicolumn{2}{|c|}{ Treatment } \\
\hline & & Male $(n=12)$ & Female $(n=11)$ & Laurel $(n=12)$ & Control $(n=11)$ \\
\hline Albumin g/dL & $3.26 \pm 0.02$ & $3.31 \pm 0.033$ & $3.22 \pm 0.035$ & $3.25 \pm 0.032$ & $3.28 \pm 0.033$ \\
\hline AST U/L & $44.78 \pm 3.74$ & $49.91 \pm 5.56$ & $39.32 \pm 5.85$ & $43.09 \pm 5.33$ & $46.14 \pm 5.59$ \\
\hline Phosphorus mg/dL & $8.96 \pm 0.24$ & $9.00 \pm 0.36$ & $8.95 \pm 0.38$ & $8.76 \pm 0.35$ & $9.19 \pm 0.37$ \\
\hline GGT U/L & $20.00 \pm 1.22$ & $19.43 \pm 1.84$ & $20.68 \pm 1.93$ & $19.22 \pm 1.76$ & $20.89 \pm 1.85$ \\
\hline Glucose mg/dL & $111.69 \pm 4.41$ & $117.22 \pm 6.46$ & $105.72 \pm 6.80$ & $110.83 \pm 6.19$ & $112.10 \pm 6.50$ \\
\hline $\mathrm{Ca} \mathrm{mg} / \mathrm{dL}$ & $9.29 \pm 0.13$ & $9.11 \pm 0.20$ & $9.47 \pm 0.21$ & $9.40 \pm 0.19$ & $9.18 \pm 0.20$ \\
\hline Cholesterol mg/dL & $123.13 \pm 5.43$ & $122.60 \pm 8.11$ & $123.29 \pm 8.53$ & $127.52 \pm 7.77$ & $118.36 \pm 8.15$ \\
\hline Triglyceride $\mathrm{mg} / \mathrm{dL}$ & $28.39 \pm 3.23$ & $33.78 \pm 3.93$ & $23.20 \pm 4.14$ & $20.84 \pm 3.77^{\mathrm{a}}$ & $36.14 \pm 3.95^{b}$ \\
\hline $\mathrm{T} 4 \mathrm{nmol} / \mathrm{L}$ & $91.44 \pm 7.91$ & $77.43 \pm 10.55$ & $107.84 \pm 11.10$ & $80.42 \pm 10.11$ & $104.85 \pm 10.60$ \\
\hline $\mathrm{T} 3 \mathrm{nmol} / \mathrm{L}$ & $3.02 \pm 0.21$ & $2.42 \pm 0.27^{\mathrm{a}}$ & $3.67 \pm 0.29^{\mathrm{b}}$ & $3.14 \pm 0.26$ & $2.96 \pm 0.27$ \\
\hline Globulin g/dL & $2.59 \pm 0.07$ & $2.63 \pm 0.11$ & $2.56 \pm 0.11$ & $2.51 \pm 0.10$ & $2.68 \pm 0.11$ \\
\hline Insulin $\mathrm{pmol} / \mathrm{L}$ & $102.65 \pm 12.16$ & $101.13 \pm 18.83$ & $104.71 \pm 19.81$ & $98.40 \pm 18.05$ & $107.44 \pm 18.93$ \\
\hline $\mathrm{GH}$ ng/mL & $5.27 \pm 0.20$ & $5.43 \pm 0.29$ & $5.11 \pm 0.31$ & $5.15 \pm 0.28$ & $5.39 \pm 0.29$ \\
\hline Creatinine mg/dL & $0.92 \pm 0.02$ & $0.95 \pm 0.035$ & $0.89 \pm 0.037$ & $0.94 \pm 0.034$ & $0.90 \pm 0.036$ \\
\hline
\end{tabular}

a,b, The differences between the mean values indicated with different letters on the same column are significant $(\mathrm{P}<0.05)$.

\section{CONCLUSION AND RECOMMENDATIONS}

The objective of this study was to determine the effects of essential laurel oil added $(600 \mathrm{mg} / \mathrm{d})$ whole milk on the body weight gain, chest girth sizes, health and blood parameters of Holstein calves during suckling period.

Based on the results, addition of laurel oil into whole milk did not have significant effects on feed intake, body weight gain cost and feed conversion ratio, however it had a biologically significant effect on health parameters. These effects were considered as a feed additive containing natural growth hormone potential for calf performance. The feed intakes became lower when the diet of the calves supplemented with essential laurel oil. The improvement in feed conversion ratio and low number of days with diarrhea was the positive effects of laurel oil in calves.

The potential significant effect of essential laurel oil on calf performance might depend on the harvesting region and time of product. In this study, the amount of the active ingredient given per $\mathrm{kg}$ of body weight was low, which may be the reason of observed insignificancy in certain parameters. Finally, fixed milk consumption versus lower roughage use during milk suckling period may preclude these results. Therefore, additional experimental designs for feeding programs are needed with various doses.

\section{ACKNOWLEDGMENTS}

The author wish to thank to Kahramanmaraş Sütçü
İmam University, Department of Scientific Research Project Coordination. This study was supported by Kahramanmaraş Sütçü İmam University, Department of Scientific Research Project Coordination. Project No: 2014/3-5 YLS.

\section{Statement of conflicts of interest}

The authors certify that they have no affiliations with or involvement in any organization or entity with any financial interest (such as honoraria, educational grants, participation in speakers' bureaus, membership, employment, consultancies, stock ownership, or other equity interest, and expert testimony or patent-licensing arrangements), or non-financial interest (such as personal or professional relationships, affiliations, knowledge or beliefs) in the subject matter or materials discussed in this manuscript.

\section{REFERENCES}

Abascal, K. and Yarnell, E., 2002. Herbs and drug resistance: Part 1-Herbs and microbial resistance to antibiotics. Altern. Complem. Therap., 8: 237-241. https://doi.org/10.1089/107628002320351370

Ahmed, A.A., Bassuony, N.I., El-Habiab, S.A., Awad, S., Aiad, A.M. and Mohamed, S.A., 2009. Adding natural juice of vegetables and fruitage to ruminant diets (B) nutrients utilization, microbial safety and immunity, effect of diets supplemented with lemon, 
onion and garlic juice fed to growing buffalo calves. World J. Agric. Sci., 5: 456-465.

Akkan, S., 2013. Effects of using Saccharomyces cerevisiae and mannan oligosaccharide in the liquid feeding period on performance of calves. $\mathrm{PhD}$ thesis, Ege University, Graduate School of Natural and Applied Sciences Department of Animal Science İzmir, Türkiye

Alçiçek, A., Bozkurt, M. and Çabuk, M., 2003. The effect of essential oil combination derived from selected herbs growing wild in Turkey on broiler performance. S. Afri. Soc. Anim. Sci., 33: 89-94.

Altundağ, S. and Aslım, B., 2005. Thyme's Antimicrobial Effect on Some Plant Pathogenic Bacteria. J. Orlab On-Line Microbiol., 3: 5-14.

Anonymous, 2002. Production, import, export, sale and use of feed additives and premixes. Number: 24967, Notification No: 2002/66. http://www.resmigazete. gov.tr/eskiler/2002/12/20021218.htm\#6

Anonymous, 2005. Communiqué on the participation in mixed feeds and the prohibition of feeding animals. Number: 25847, Notification No: 2005/24. http://www.resmigazete.gov.tr/eskiler/2005 /06/20050616-13.htm

Anonymous, 2006. Communiqué on the amendment of the communique on the production, importation, export, sale and use of feed additives and premixes. Number: 26056, Notification No: 2006/1. http://www.resmigazete.gov.tr/ eskiler/2006/01/20060121-8.htm

Benchaar, C., Duynisveld, J.L. and Charmley, E., 2006. Effects of monensin and increasing dose levels of a mixture of essential oil compounds on intake, digestion and growth performance of beef cattle. Canadian J. Anim. Sci., 86: 91-96.

Berge, A.C.B., Lideque, P., Moore, D.A., Sischo, W.M., 2005. A clinical trial evaluating prophylactic and therapeutic antibiotic use on health and performance of preweaned calves. J. Dairy Sci., 88: 2166-2177. https://doi.org/10.3168/jds.S0022-0302(05)728927

Büyükkiliç-Beyzi, S., 2012. Effects of probıotıc as a feed additive on performance and fecal characteristics of calves. Master thesis, Ankara University Graduate School of Natural and Applied Sciences Department of Animal Science, Ankara, Türkiye

Cardozo, P.W., Calsamiglia, S., Ferret, A. and Kamel, C., 2006. Effects of alfalfa extract, anise, capsicum, and a mixture of cinnamaldehyde and eugenol on ruminal fermentation and protein degradation in beef heifers fed a high-concentrate diet. J. Anim. Sci., 84: 2801-2808. https://doi.org/10.2527/ jas.2005-593

Çabuk, M., Alçiçek, A., Bozkurt, M. and İmre, N., 2003. Possibilities of using antimicrobial properties of essential oils obtained from aromatic plants and as an alternative feed additive. II. National Animal Feeding Congress, pp.184-187.

Chaves, A.V., Stanford, K., Gibson, L.L., McAllister, T.A. and Benchaar, C., 2008. Effects of carvacrol and cinnamaldehyde on intake, rumen fermentation, growth performance, and carcass characteristics of growing lambs. Anim. Feed Sci. Technol., 145: 396-408. https://doi.org/10.1016/j. anifeedsci.2007.04.016

Donovan, D.C., Franklin, S.T., Chase, C.C.L. and Hippen, A.R., 2002. Growth and health of holstein calves fed milk replacers supplemented with antibiotics or enteroguard. J. Dairy Sci., 85: $947-950$. https://doi.org/10.3168/jds.S00220302(02)74153-2

Dziba, L.E., Hall, J.O. and Provenza, F.D., 2006. Feeding behavior of lambs in relation to Kinetics of 1,8-Cineole dosed intravenously or into the rumen. J. Chem. Ecol., 32: 391-408. https://doi. org/10.1007/s10886-005-9009-4

Ertekin, M., Kırdar, E., Sezgin, Ayan, N. and Özel, H.B., 2009. The effects of some plant growth regulator on seedling of laurel (Laurus nobilis L.). Kastamonu Univ. J. Forest. Facul., 9: 171-176.

Evren, M. and Tekgüler, B., 2011. Antimicrobial properties of essential oils. J. Electron. Microbiol.., 9: $28-40$.

Garcia, M., Shin, J.H., Schlaefli, A., Greco, L.F., Maunsell, F.P., Santos, J.E.P., Staples, C.R.and Thatcher, W.W., 2015. Increasing intake of essential fatty acids from milk replacer benefits performance, immune responses, and health of preweaned holstein calves. J. Dairy Sci., 98: 458477. https://doi.org/10.3168/jds.2014-8384

Ghosh, S., Mehla, R.K., Sirohi, S.K., Tomar S.K. and Roy B., 2010a. Performance of crossbred calves with dietary supplementation of garlic extract. Indian J. Anim. Sci., 80: 690-692.

Ghosh, S., Mehla, R.K., Sirohi, S.K. and Roy B., 2010b. The effect of dietary garlic supplementation on body weight gain, feed intake, feed conversion efficiency, faecal score, faecal coliform count and feeding cost in crossbred dairy calves. Trop. Anim. Hlth. Prod., 42: 961-968. https://doi.org/10.1007/ s11250-009-9514-5

Ghosh, S., Mehla, R.K., Sirohi, S.K. and Tomar, S.K., 2011. Performance of crossbred calves with dietary supplementation of garlic extract. J. Anim. Physiol. 
Anim. Nutr., 95: 449-455. https://doi.org/10.1111/ j.1439-0396.2010.01071.x

Helander, I.M., Alakomi, H.L., Latva-Kala, K., MattilaSandholm, T., Pol, I., Smid, E.J., Gorris, L.G.M. and von Wright, A., 1998. Characterization of the action of selected essential oil components on gram-negative bacteria. J. Agric. Fd. Chem., 46: 3590-3595. https://doi.org/10.1021/jf980154m

Karaoğul, E., Ertaş, E., Altuntaş, E. and Alma, M.H., 2012. The chemical composition of Laurel (Laurus nobilis) grow in The Black Sea and Mediterranean Regions. I. National Mediterranean Forest and Environment Symposium, 26-28 October 2011, Kahramanmaraş, Turkey.

Karayağız, İ. and Bülbül, T., 2014. Feed additives effective on productive performance in ruminants. J. Ataturk Uni. Vet. Sci., 9: 124-133.

Koçyiğit, R., Aydın, R., Yanar, M., Diler, A., Avcı, M. and Özyürek, S., 2016. The Effect of directfed microbials plus exogenous feed enzyme supplements on the growth, feed efficiency ratio and some behavioural traits of Brown Swiss $\mathrm{x}$ Eastern Anatolian Red F1 calves. Pakistan J. Zool., 48: $1389-1393$

Kutlu, T. and Erdoğan, Z., 2010. Phytobiotic feed additives in poultry feding. 1st National Poultry Congress, Kayseri, 7-9 October 2010.

Larson, L.L., Owen, F.G., Albright, J.L., Appleman, R.D., Lamb, R.C. and Muller, L.D., 1977. Guidelines toward more uniformity in measuring and reporting calf experimental data. J. Dairy Sci., 60: 989-991. https://doi.org/10.3168/jds.S00220302(77)83975-1

McIntosh, F.M., Newbold, C.J., Losa, R., Williams, P. and Wallace, R.J., 2000. Effects of essential oils on rumen fermentation. Reprod. Nutr. Develop., 40: 221-222.

Morrill, J.L., Dayton, A.D. and Mickelsen, R., 1977. Cultured milk and antibiotics for young calves. $J$. Dairy Sci., 60: 1105-1109. https://doi.org/10.3168/ jds.S0022-0302(77)83995-7

Özalpaydın, H.B., 2014. The effects of oregano oil usage in milk on holstein calf growth performance. Master thesis, Mustafa Kemal University, Graduate School of Natural and Applied Sciences Department of Animal Science, Hatay, Turkey.

Radostits, O.M., Gay, C.C. and Hinchcliff, K.W., 2008. Veterinary medicine (ed. P.D. Constable), $10^{\text {th }}$ Edition. Saunders Elsevier, Toronto.

SAS, 2000. SAS user's guide, $5^{\text {th }}$ edition. SAS Inc., Cary, NC.

Simitzis, P.E., Deligeorgis, S.G., Bizelis, J.A.,
Dardamani, A., Theodosiou, I. and Fegeros, K., 2008. Effect of dietary oregano oil supplementation on lamb meat characteristics. Meat Sci., 79: $217-$ 223. https://doi.org/10.1016/j.meatsci.2007.09.005

Sirakaya, S., 2008. Effects of mannan oligosaccharides and chromium in performance of calves consuming milk. Master thesis, Erciyes University, Institute of Health, Department of Animal Nutrition and Nutritional Diseases, Kayseri, Turkey.

Smith-Palmer, A., Stewart, J. and Fyfe, L., 2002. Inhibition of listeriolysin $\mathrm{O}$ and phosphatidylcholine-specific production in listeria monocytogenes by sub-inhibitory concentrations of plant essential oils. J. med. Microbiol., 51: 567608. https://doi.org/10.1099/0022-1317-51-7-567

Soltan, M.A., 2009. Effect of essential oils supplementation on growth performance, nutrient digestibility, health condition of holstein male calves during pre-and post-weaning periods. Pakistan J. Nutr., 8: 642-652. https://doi. org/10.3923/pjn.2009.642.652

Spanghero, M., Zanfi, C., Fabbro, E., Scicutella, N. and Camellini, C., 2007. Effect of milk replacers added with microencapsulated organic acids or essential oils on the performance of weaning calves. Italian J. Anim. Sci., 6: 366.

Tunç, M.A., 2012. The effect of humat and probiotics on performance, rumen fermantation and blood parameters in milk suckling period of calves. $\mathrm{PhD}$ thesis, Atatürk University, Institute of Health, Department of Animal Nutrition and Nutritional Diseases, Erzurum, Türkiye.

Ünal, A., 2011. Effect of essential oregano oil on performance, some blood and rumen parameters and carcass characteristics in lambs. $\mathrm{PhD}$ thesis, İstanbul University, Institute of Health, Department of Animal Nutrition and Nutritional Diseases, İstanbul, Türkiye.

Ünlü, H. and Erkek, R., 2013. Effects of oregano and garlic essential oils on performance of calves and some parameters of faeces and blood. Ege Üni. J. Agric. Facult., 50: 299-310.

Vakili, A.R., Khorrami, B., Mesgaran, M.D. and Parand, E., 2013. The effects of thyme and cinnamon essential oils on performance, rumen fermentation and blood metabolites in holstein calves consuming high concentrate diet. AsianAustral. J. Anim. Sci., 26: 935-994. https://doi. org/10.5713/ajas.2012.12636

Van der Vliet, H. and Cardozo, P.W., 2013. Head-start strategies for optimal calf rearing. Int. Dairy Top., 7: 13-15. 
Wenk, C., 2000. Why all the discussion about herbs? IN: Alltech, 16th Ann. Symp. Biotechnol. in the Feed Industry (Ed. Lyons, T.P.). Alltech Tech. Publ., Nottingham, University Press, Nicholasville, KY. pp. 79-96.

Yang, W.Z., Ametaj, B.N., Benchaar, C., He, M.L. and Beauchemin, K.A., 2010. Cinnamaldehyde in feedlot cattle diets: Intake, growth performance, carcass characteristics, and blood metabolites. $J$. Anim. Sci., 88: 1082-1092. https://doi.org/10.2527/ jas.2008-1608

Youssef, M.M., Abo-Donia, F.M., Afify, A.A. and Osman, A.O., 2008. Effect of added Punica granatum peel and Nigella sativa seeds on immunology and performance of suckling buffalo claves. In: Proceedings of the Middle East \& North Africa (MENA) Region Animal Wealth Research Conference, Future of Animal Wealth, Cairo International Convention Center, Massive Conferences and Trade Fair, pp. 293-305. 